\title{
原著論文
}

\section{熱膨張抑制埋没材を用いたときの鋳造冠の 変形阅する関究}

\author{
根住 正博 \\ Deformation of Crowns Cast in Thermal Expansion \\ Inhibited Investment
}

Masahiro Nezumi

\begin{abstract}
Experimentally thermal expansion inhibited investment was produced to discuss a problem, the compensation of metal casting shrinkage is to be dependent upon setting expansion. Using the various concentration of colloidal silica solution as mixing liquid, idealized full cast crowns were made, the each size were measured and the following results were obtained.

On this investment :

1. As the more concentration of silica, the more expansion appeared.

2. The shrinkage in cooling is slight.

3. The expansion in ringless method is greater than that of ring method.

On the deformation of crowns:

1. In the external width, both ring and ringless method in $10 \%$ and $20 \%$ showed shrinkage, the more concentration, expansive tendency appeared. The inhibition of expansion appeared in $40 \%$ by ring method. The expansion of cervical showed larger than occlusal.

2. Internal width in $10 \%$ appeared shrinkage by both methods, they showed more expansion, increasing of concentration. The internal tendency appeared that occlusal was greater than cervical. The expansion of internal showed greater than external.

3. Despite of methods the more expansion appeared, increasing concentration. The more expansion appeared in the internal height than in external.

The mention above following conclusion were obtained.

It was cleared that the various deformation of crowns appeared due to the setting expansion of investment alone. Accordingly it was considered that the deformation occur in the stage of setting expansion before thermal stage in the present dental casting procedure. It can be said that the setting expansion is the great factor of the deformation in cast crowns.
\end{abstract}

Key words : investment, setting expansion, cast crowns, deformation

大阪歯科大学歯科補称学第一講座 (主任 : 権田悦通教授)

The First Department of Prosthodontics, Osaka Dental
University (Chief : Prof. Yoshimichi Gonda) 平成 2 年 12 月 10 日受付 


\section{I. 緒言}

インレー・クラウン・ブリッジ・鋳造床などに代表さ れる歯科分野における鋳造修復物は，近年ますますその 精密化が要求されるようになってきた.

歯科界における鋳造法は, Coleman ${ }^{1)}$ 以来ロストワッ クス法による埋没材の硬化時の膨張や熱膨張を利用して 金属の鋳造收縮を補う方法がとられてきた. その後，多 くの研究者によって ${ }^{2 \sim 10)}$ ，鋳造技術や使用材料の改良. 開発が行われた結果，鋳造精度も大きく向上し，臨床的 に十分通用し得る鉡造体が得られるようになってきた。 しかし一方では，鋳造体をさらに詳細に研究した結 果 ${ }^{11 \sim 16)}$, 厚さを含む鋳造体各部の変形が指摘されるよう になり，作製した鋳造体が蝜型と同形・同大でないこと も明らかにされてきた. これらの変形の原因について, 最近では埋没材の硬化時膨張の異方性が注目されるよう


を伴った鋳造体を作る原因となっていることが明らかに された ${ }^{13,15,26 \sim 28)}$. また, Junner ら ${ }^{24)}$ は埋没時に用いるリ ングの材料を変えて硬化時膨張を測定し, リングの有無 にかかわらず縦方向と横方向の膨張量に有意の差がみら れることを，Jorgensen ら ${ }^{10)}$ は鋳造用合金の収縮を補償 するために鋳型材の硬化時膨張を利用することは精度的 観点から好ましくないことを報告している。，一方，近年 になって，鋳造収縮の大きな歯科用卑金属合金が応用さ れるようになり，その補償には熱膨張だけでなく硬化時 膨張にも依拠して, 埋没材のさらに大きな膨張が要求さ れていることも事実である.

著者の所属する講座においても，このような金属の鋳 造収縮を補償するための埋没材の膨張について，硬化時 膨張のみに依拠するべきか，熱膨張のみによるべきか， あるいは従来と同様にその両者を利用すべきかについて 1980 年以来検討を加えてきた. まず筆本 ${ }^{13)}$ は, 硬化時に も加熱時にも膨張しない無膨張埋没材を試作し，これを 用いて作製した鋳造冠は測定部位に関係なく，蠟型とほ ぼ相似形的な寸法変化をすることを明らかにした．次い
で小正 ${ }^{15)}$ は，硬化時膨張抑制埋没材を試作し，熱膨張の みで金属の鋳造收縮を補償すると，変形の少ない適合性 の良い鋳造冠が得られることを報告した。

そこで今回著者は，硬化時の膨張のみで金属の鋳造収 縮を補償することに着目し，次の 2 つの実験からその可 否を検討することにした. まず実験 1 として，硬化時膨 張のみで熱膨張を極力小さくし，しかもリングレス法で も鋳造操作に耐え得るリン酸塩系の熱膨張抑制埋没材を 試作し, 練和液として用いるコロイダルシリカ溶液の濃 度を変化させたときの鋳型材としての諸性質を測定し た. 次に, 実験 2 として, 試作した熱膨張抑制埋没材を 用い，各種濃度のコロイダルシルカ溶液で硬化膨張量を 変化させて作製した鋳造冠各部の寸法変化を検討した. なお，これらの対照としては筆本 ${ }^{13)}$ の無膨張埋没材によ る鋳造冠を用いた。

\section{II. 実験 1. 熱膨張抑制埋没材の試作}

\section{1. 実験材料およひ実験方法}

1) 材料とその配合比

熱膨張抑制埋没材の材料は，熱膨張が非常に小さい無 膨張埋没材の耐火材と結合材を主成分とし，その配合比 も無膨張埋没材の配合比を基準とした．すなわち，耐火 材として硅酸ジルコニウム $\left(\mathrm{ZrSiO}_{4}\right)$, クリストバライト $\left(\mathrm{SiO}_{2}\right)$, 溶融石英 $\left(\mathrm{SiO}_{2}\right)$ を, 結合材として第1リン酸ア ンモニウム $\left(\mathrm{NH}_{4} \mathrm{H}_{2} \mathrm{PO}_{4}\right)$ と酸化マグネシウム $(\mathrm{MgO})$ を用いた. 無膨張埋没材と熱膨張抑制埋没材の配合比を 表 1 に示す.

2) 試料の練和

練和液には硬化時膨張が大きく現れるコロイダルシリ 力溶液を用い， $10 ， 20,30,40 \%$ の 4 種類の濃度について 実験した．混液比はいずれも埋没材 $100 \mathrm{~g}$ に対して 16 $\mathrm{cc}$ 一定とし, 練和は, 15 秒閒の手練和ののち, 定格回転 数 $120 \mathrm{rpm}$ の真空練和機（而至歯科工業社製，バキュー ムミキサー HM-I 型)を用いて 60 秒間の機械練和を行 った.

表 1 使用埋没材の材料とその配合比

\begin{tabular}{lccccc}
\hline \hline Raw Material & $\mathrm{ZrSiO}_{4}$ & $\begin{array}{c}\mathrm{SiO}_{2} \\
\text { (Cristobalite) }\end{array}$ & $\begin{array}{c}\mathrm{SiO}_{2} \\
\text { (Fused Quartz) }\end{array}$ & $\mathrm{NH}_{4} \mathrm{H}_{2} \mathrm{PO}$ & MgO \\
\hline N.E. & 30 & 35 & 15 & 10 & 10 \\
T.E. & 40 & 20 & 20 & 10 & 10 \\
\hline N.E. : Non-Expansion Investment & & & (Wt \%) \\
T.E. : Thermal Expansion Inhibited Investment &
\end{tabular}




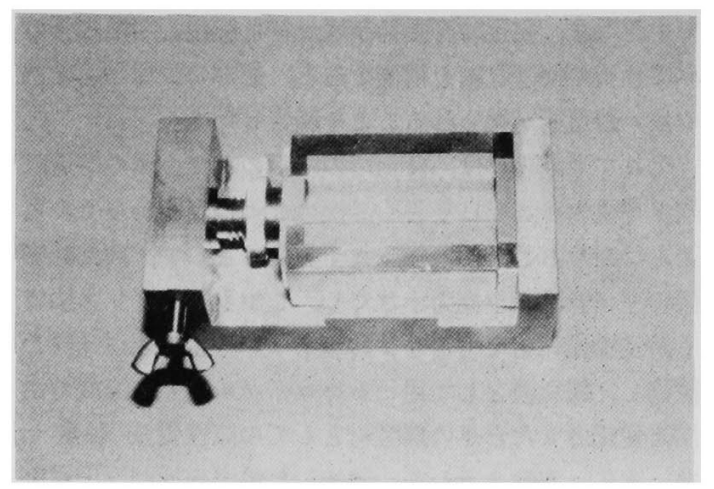

図 1 硬化膨張測定用半円形トレー

3）硬化時間の測定

測定は JIS 規格凝固時問試験に従い，内径 $25 \mathrm{~mm}$, 高 さ $30 \mathrm{~mm}$ のゴムリングを乾燥したガラス板上に置き, 練和した試料をリング内へ注入したのち，重さ $300 \mathrm{~g}$, 直径 $2 \mathrm{~mm}$ のヴッカー針を用い, 練和開始から試料中に $1 \mathrm{~mm}$ 入るまでの時間を硬化時間とした.

4) 硬化時膨張と熱膨張の測定

硬化時膨張は, 筆本 ${ }^{13)}$ が考案した硬化膨張測定用半円 形トレー（図 1) を用いて試料練和開始から 2 時問測定 した.この測定装置は, 試料の自由な膨張を測定・記録 する目的で緩衝材が入るスペースを設けてあり，同時に 同一試料による熱膨張測定が可能なように寸法を定めて ある．熱膨張は硬化時膨張を計測したのち，同一試料を 直ちに熱膨張測定装置にセットし，昇温速度 $5^{\circ} \mathrm{C} / \mathrm{min}$ で $900^{\circ} \mathrm{C}$ まで昇温させて計測し, その後, 電気炉を開放 して $200^{\circ} \mathrm{C}$ ま゙泠却して収縮量を測定した. なお, 硬化 時膨張と熱膨張の総和をトータル膨張とした. また, 緩 衝材には，実験 2 の鋳造冠作製時に使用するのと同じ, 厚さ $2 \mathrm{~mm}$ のシリコーンラバー（而至歯科工業社製）と 厚さ $1 \mathrm{~mm}$ のカオウール (イソライト社製) の 2 種類を 用いた.

5）圧縮強さの測定

圧縮強さの測定は JIS 規格破砕抗力試験に従った。す なわち, 内径 $20 \mathrm{~mm}$, 高さ $30 \mathrm{~mm}$ の金属円筒割型に練 和した試料を注入し, 硬化後, 割型から抜取って室温中 に保存して測定試料とした. 測定は練和開始 24 時閒 後 の乾燥強度, および練和開始 1 時間後に電気炬に入れ, 昇温速度 $5^{\circ} \mathrm{C} / \mathrm{min}$ で $900^{\circ} \mathrm{C}$ まで昇温し, 30 分間係留し たのち室温まで放冷した焼成強度について行った. 測定 にはオートグラフ（島津製作所社製 AG-5000 A) を用 い,クロスヘッドスピード $10 \mathrm{~mm} / \mathrm{min}$ で行った.

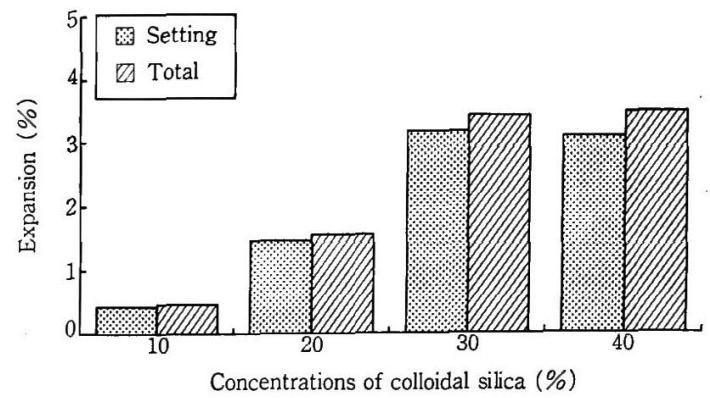

图 2 無膨張埋没材を各コロイダルシリカ溶液で練和 したときの硬化膨張とトータル膨張

\section{2. 実験結果ならびに考察}

熱膨張抑制埋没材の試作には，加熱時に熱膨張がほと んど現れない無膨張埋没材の耐火材と結合材を主成分と して使用した. しかし，無膨張埋没材は水で練和するた め, 硬化時膨張も現れない. 一方, リン酸塩系埋没材を コロイダルシリカ溶液で練和すると，硬化時に大きく膨 張することや，コロイダルシリカ溶液の濃度を変化させ ると埋没材の膨張量を調節できることはすでに知られて いる ${ }^{29,30)}$ ，そこで今回の実験では，まずリン酸塩系埋没 材である無膨張埋没材を濃度 $10,20,30,40 \%$ の 4 種類 のコロイダルシリカ溶液で練和してみることにした. な お，混液比は $16 \mathrm{cc}$ 一定とした. その結果を図 2 に示す. グラフの縦軸には膨張量の寸法変化率を, 横軸には練和 液のコロイダルシリカ溶液の濃度を表している．硬化時 膨張・トータル膨張ともにコロイダルシリカ溶液濃度が 増加するに従って大きくなる傾向が認められた. また, 濃度 $10 \%$ では硬化時膨張とトータル膨張がほぼ等しい 值を示し，ほとんど熱膨張は示さなかった。しかし，濃 度が $20 \%$ から 40\% と增すに従ってトータル膨張が硬化 時膨張より大きくなり, 熱膨張が現れる結果となった.

水で練和すると硬化時膨張も熱膨張も現れなかった無 膨張埋没材が, コロイダルシリカ溶液で練和すると膨張 が現れた原因は, 硬化時膨張についてはコロイダルシリ 力溶液中のシリカ粒子の存在によって保水能を有するゲ ルが生成され，このゲルが $\mathrm{NH}_{4} \mathrm{MgPO}_{4} \cdot 6 \mathrm{H}_{2} \mathrm{O}$ の結晶 生成に対し吸水膨張として働き, 大きな柱状結晶を形成 する結果であるといわれている31 33).さらにシリカ濃度 が増加すると存在するシリカ粒子の充填密度が大きくな るため,より大きな膨張が得られることになる.

一方，熱膨張については，加熱によって耐火材の粒子 が互いにぶつかりあいつつ膨張するとき，その粒子閒に シリカ粒子が存在すると，シリカ粒子の介在によって水 
表 2 試作熱膨張抑制埋没材の物理的性質

\begin{tabular}{|c|c|c|c|c|c|}
\hline \multirow{2}{*}{ Liqud } & & \multirow{2}{*}{$L / P$} & \multirow{2}{*}{$\begin{array}{l}\text { Setting } \\
\text { Time (min) }\end{array}$} & \multicolumn{2}{|c|}{ Compressive Strength $\left(\mathrm{kg} / \mathrm{cm}^{2}\right)$} \\
\hline & & & & 24 hours & Heating \\
\hline & 10 & 0.16 & 13.5 & 235 & 92 \\
\hline Colloidal & 20 & 0.16 & 12.4 & 299 & 195 \\
\hline silica & 30 & 0.16 & 11.6 & 389 & 227 \\
\hline$(\%)$ & 40 & 0.16 & 10.7 & 506 & 365 \\
\hline \multirow{3}{*}{\multicolumn{2}{|c|}{ Liqud }} & \multicolumn{4}{|c|}{ Expansion (\%) } \\
\hline & & \multicolumn{2}{|c|}{ Silicone rubber } & \multicolumn{2}{|c|}{ Kaowool liner } \\
\hline & & $\begin{array}{l}\text { Setting } \\
\text { (2 hours) }\end{array}$ & $\begin{array}{l}\text { Total } \\
\left(900^{\circ} \mathrm{C}\right)\end{array}$ & $\begin{array}{l}\text { Setting } \\
\text { (2 hours) }\end{array}$ & $\begin{array}{l}\text { Total } \\
\left(900^{\circ} \mathrm{C}\right)\end{array}$ \\
\hline & 10 & 0.58 & 0.38 & 0.29 & 0.14 \\
\hline Colloidal & 20 & 1.63 & 1.52 & 1.27 & 1.17 \\
\hline silica & 30 & 2.64 & 2.64 & 2.13 & 2.13 \\
\hline$(\%)$ & 40 & 3.07 & 3.11 & 2.64 & 2.74 \\
\hline
\end{tabular}

で練和したときよりも大きな体積の増加がみられ，結果 として熱膨張として現れたと思われる。

また，コロイダルシリカ溶液濃度が増すに従って熱膨 張が大きく現れたのは，耐火材の粒子間に存在するシリ 力粒子の密度が大きくなるため, および，筆本が無膨張 埋没材の試作にあたって，230 350 ${ }^{\circ} \mathrm{C}$ 付近の加熱時に みられるリン酸塩系埋没材特有の結晶水の脱水ならびに アンモニアガスの放出による大きな収縮を補うため，耐 火材中のクリストバライトの添加量を $35 \%$ と大きくす ることによってその収縮を補償し，熱膨張を0にしてい るためと考えられる，そこで本実験では，クリストバラ イトの添加量を減らすことによって熱膨張を抑制するこ とが必要であり，筆本の推定值からその量は $20 \%$ が適 当であると考えた（表 1$).$

次に，試作熱膨張抑制埋没材の諸性質について述べる (表 2).

硬化時間はコロイダルシリカ溶液の濃度に影響を受 け，コロイダルシリカ溶液の濃度が増すほど短くなっ た，この硬化時間は鋳型がある程度の強さになるまでの 時間であり，コロイダルシリカ溶液の濃度が増加するに 従って早期に, 強度が大きくなる結果, 短くなったと考 えられる。

圧縮強度は, 乾㷥強度 $235 \sim 506 \mathrm{~kg} / \mathrm{cm}^{2}$, 焼成強度 92 $\sim 365 \mathrm{~kg} / \mathrm{cm}^{2}$ と, シリカ濃度が増加するに従って大きく なる傾向がみうけられたが，いずれも市販埋没材の 2 倍 以上の強度を有していた．これらの強度はリングレス法 による鋳造操作に十分耐え得るものである.

次化, 試作熱膨張抑制埋没材の硬化時膨張と熱膨張を
測定した。な扔，緩衝材は実験 2 の鋳造冠作製時に使用 するのと同じ $2 \mathrm{~mm}$ 厚さのシリコーンラバーと, $1 \mathrm{~mm}$ 厚さのカオウールを用いた. 図 3 は緩衝材としてシリコ ーンラバーを用いた時の, 図 4 はカオウールを使用した 時の膨張曲線で, 図 5,6 にはそれぞれの硬化時膨張 と トータル膨張の実験結果を示した。 図から明らかなよう に硬化時膨張・トータル膨張ともにコロイダルシリカ浱 度が増加するに従って, 緩衝材の種類に関倸なく大きく 膨張する傾向が認められた，また，図 $3 ， 4$ の膨張曲線 から明らかなように, この埋没材の $900^{\circ} \mathrm{C}$ 加熱後の冷 却収縮はこれまでの市販埋没材よりも小さい，これは従 来の市販埋没材では加熱時に膨張する而火材の量が多 く, 泠却時にはその膨張分だけ収縮するのに対し, 硬化 時に大きく膨張する本埋没材では冷却時の収縮は小さ く，大きな膨張が残るのが特徴である．特にシリカ濃度 $30,40 \%$ の場合は著明である. そして, 図 5, 6 の結果 からも明らかなように，いずれの緩衝材を用いても硬化 時膨張とトータル膨張がほぼ等しい值を示し, 熱膨張が よく抑制されていた. しかし、コロイダルシリカ濃度が $10 \%$ と $20 \%$ のものでは, 硬化時膨張がトータル膨張よ りもわずかに大きく現れた。これは練和液中の分散媒と してのコロイダルシリカの濃度が少なすぎるために, 加 熱時に結合材の収縮が現れたためである.

一方, 膨張の程度はいずれのシリカ濃度においても， シリコーンラバーを用いた方がカオウールを使用したも のよりも大きい值を示した.これは，埋没材の硬化時膨 張発現直後からの膨張に対する緩衝材のクッション効果 の差が影響しているのではないかと考えられる. 


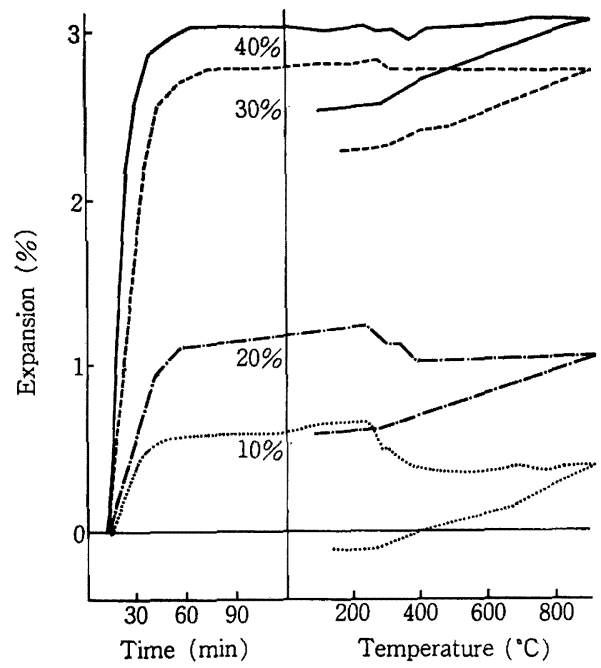

図 3 熱膨張抑制埋没材を各コロイダルシリカ溶液 で練和したときの膨張曲線（緩衝材にシリコ ーンラバーを用いた場合)

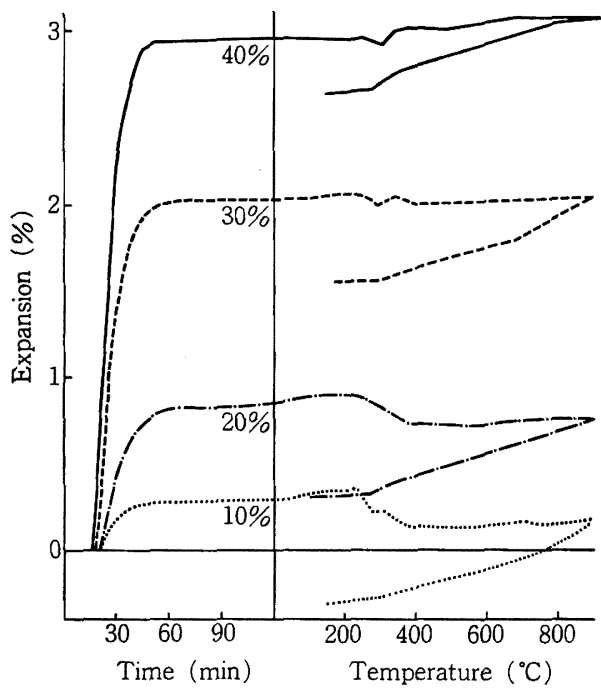

図 4 熱膨張抑制埋没材を各コロイダルシリカ溶液 で練和したときの膨張曲線（緩衝材にカオウ ールを用いた場合)

そこで，シリコーンラバーとカオウールの圧縮ひずみ 量を知る目的で, 両者の圧縮試験を行った. すなわち, 厚さ $2 \mathrm{~mm}$ のシリコーンラバーと同じ厚さのカオウー ル，および本実験に使用した厚さ $1 \mathrm{~mm}$ のカオウール を, おのおの $5 \mathrm{~cm}$ 平方の試験片とし, 圧縮試験機（島津 製作所社製オートグラフ AG-5000 A) を用いてクロスへ ッドスピード $1.0 \mathrm{~mm} / \mathrm{min}$ で連続的に加重し, その歪量

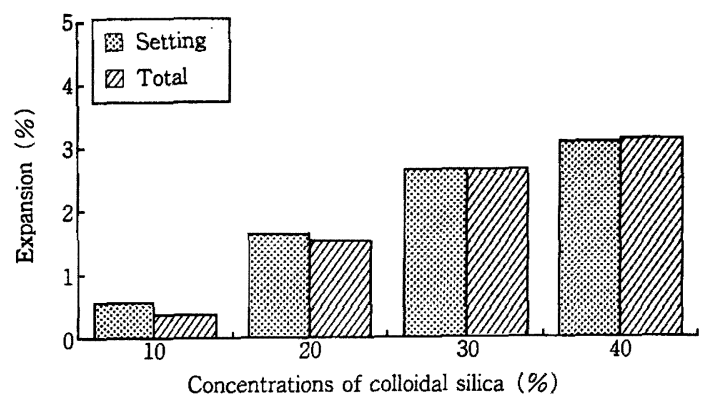

図 5 熱膨張抑制埋没材の硬化膨張とトータル膨張 （緩衝材にシリコーンラバーを用いた場合）

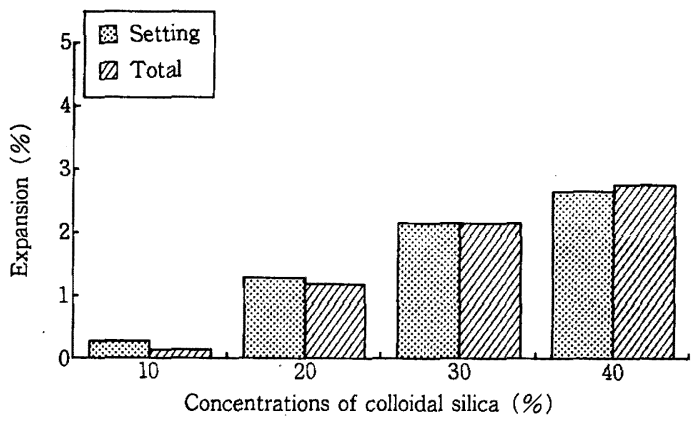

図 6 熱膨張抑制埋没材の硬化膨張とトータル膨張 （緩衝材にカオウールを用いた場合）

を求めた.図 7 は各試料の $10 \mathrm{~mm}$ 平方あたりの加重と歪 量の関係を示している. 厚さ $2 \mathrm{~mm}$ のシリコーンラバー では, $0.5 \mathrm{~kg}$ 加重時に $0.83 \mathrm{~mm}, 1 \mathrm{~kg}$ で $1.13 \mathrm{~mm}, 1.5$ $\mathrm{kg}$ で $1.28 \mathrm{~mm}$ と加重量が増加するに従って歪量も増加 する傾向が認められた. 厚さ $2 \mathrm{~mm}$ のカオウールでは歪 量はシリコーンラバーと同じように加重量が増加するに 従って增す傾向はみられるがその程度は小さく，シリコ ーンラバーの方がカオウールよりを緩衝能力のあること が明らかとなった．また，本実験に用いた $1 \mathrm{~mm}$ 厚さの カオウールでは, さらに歪量が少なく, 緩衝能力が劣る ことが推察される.このことから前述の実験の結果が, 緩衝材の緩衝能力の差によって生じたことが明らかとな った.

以上の結果から，試作した熱膨張抑制埋没材は練和液 のコロイダルシリカ溶液の濃度を変化させれば硬化膨張 量を任意に調節が可能で，最高 $3 \%$ 程度の硬化時膨張を 得ることができる.また，強度も大きいためリングレス 鋳造にも適しており，鋳造収縮の大きな金属でも十分に 補償することが可能と思われる.そこで次に，この熱膨 張抑制埋没材を用いて作製した鋳造冠の変形の様相につ 


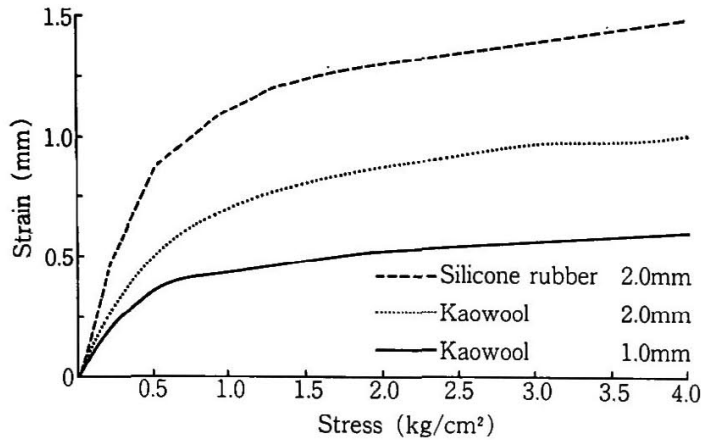

図 7 緩衝材の圧縮歪量

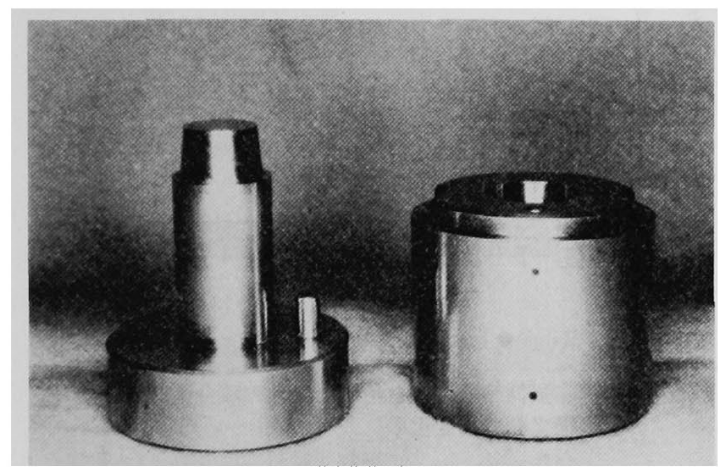

図8 金属原型

いて検討することにした

\section{III. 実験 2. 鋳造冠の変形について}

\section{1. 実験材料および実験方法}

1）金属原型

本実験に使用した金属原型は，全部鋳造冠の支台歯形 態を模型化したものである (図 8). 支台歯軸面部は臨床 的支台歯形態に近い $1 / 10$ テーパーとし, 歯頸部形態は 測定の都合上, 幅約 $1.0 \mathrm{~mm}$ のショルダータイプとし た. また，金属原型と蠟型の位置決め，ならびに後述の

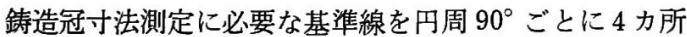
設けた。 なお，同一規格の蜖型を採得する目的で外枠も 同時に作製し，金属原型を外枠内にはめ込んで蠟型を採 得した.

\section{2）蠟型の作製}

蠟型の作製は，銿造用ワックス（而至歯科工業社製グ リーンインレーワックス, Batch No. 221141）を用いて 軟化圧接法で行い, 油圧プレス $15 \mathrm{~kg} / \mathrm{cm}^{2}$ の加重下で 24 時間保持したのち，金属原型から撤去して埋没操作に移



图 9 蠟型の埋没位置

った. なお，金属原型に印記してある基準線に沿って， 鋳造冠の寸法測定のための基準線を蛂型に印記した。 た，蠟型咬合面中央部には，蠟型の撤去時に生じる陰圧 を防ぐ目的で約 $0.8 \mathrm{~mm}$ の孔をあけ，同部は蠟型を撤去 した後にスプルーを植立して閉鎖した。

3) 埋没

蠟型は図 9 に示寸ように, 咬合面中央部に直径 2.0 $\mathrm{mm}$ の中空スプルー線 (大栄歯科産業社製) を植立し, 蠟型がリング中央に位置するように埋没した.

実験に用いた埋没材は，実験 1 で試作した熱膨張抑制 埋没材で，対照として筆本が試作した無膨張埋没材を使 用した. 埋没時の諸条件は表 3 に示す通りで, 熱膨張抑 制埋没材では, 内径 $36 \mathrm{~mm}$, 高さ $50 \mathrm{~mm}$, 厚さ $2 \mathrm{~mm}$ の シリコーンラバーリングを補強紙で加強したリングレス 法と, 内径 $40 \mathrm{~mm}$, 高さ $50 \mathrm{~mm}$ の鉄リングに厚さ $1 \mathrm{~mm}$ のカオウールを 1 枚ライニングしたリング法の 2 種類と した. また，熱膨張抑制埋没材の練和液にはコロイダル シリカ溶液を用い, $10,20,30,40 \%$ の 4 種類の濃度につ いて実験を行った. 一方, 対照とした無膨張埋没材はリ ングレス法とし，練和液は水を使用した．なお，練和は 実験 1 と同じ 15 秒間の手練和ののち， 60 秒間の真空機 械練和で行い, 埋没操作に移った.

4) 鋳造

鋳型は，埋没完了から 2 時間室温中に放置したのち， 自動昇温倸留装置付電気炉 (NEY 社製, INEY-MATIC 202-AT 型)を使用し, 約 100 分で $700^{\circ} \mathrm{C}$ まで昇温さ せ, 30 分係留したのち, 鋳造操作に移った.

鋳造は，Kメタル(而至歯科工業社製) $10 \mathrm{~g}$ を 1 回量 として用い，遠心鋳造機（モリ夕社製，CM-1）を使用し て，約 25 秒間で鋳込みまでを完了した，鋳造 冠は，鋳 型を室温まで放冷したのち取り出し, 超音波洗浄器で 15 分間洗浄して測定に供した。なお，鋳造冠は各実験条件 
表 3 使用埋没材とその埋没条件

\begin{tabular}{|c|c|c|c|c|}
\hline \multicolumn{2}{|c|}{ Material } & \multirow{2}{*}{$\begin{array}{c}\mathrm{L} / \mathrm{P} \\
(\mathrm{W} / \mathrm{P})\end{array}$} & \multirow{2}{*}{$\begin{array}{c}\text { Mixing Time (sec) } \\
\text { Hand + Mecha. }\end{array}$} & \multirow{2}{*}{ Method } \\
\hline Powder & Liquid & & & \\
\hline T.E. & $\begin{array}{ll}\text { Colloidal } & 10 \\
\text { silica } & 20 \\
(\%) & 30 \\
& 40 \\
\end{array}$ & 0.16 & $15+60$ & $\begin{array}{l}\text { Ringless } \\
\text { (Silicone rubber) } \\
\text { Ring } \\
\text { (Kaowool liner) }\end{array}$ \\
\hline N.E. & Water & 0.16 & $15+60$ & $\begin{array}{l}\text { Ringless } \\
\text { (Silicone rubber) }\end{array}$ \\
\hline
\end{tabular}



図 10 鋳造冠の測定部位

について 5 個ずつ作製した.

5） 測定方法

鋳造冠の寸法測定には, $1 / 1,000 \mathrm{~mm}$ 精度を有する万 能工具顕微鏡（東京光学社製, トプコン TUM 200 型) を用い，測定台に軟性ワックスを拈いて鋳造冠を固定 し, 水準器で平行出しをしたのち倍率 30 倍で観察し, デジタルリニアスケールカウンター (三豊社製) で読み 取った．図 10 に鋳造冠の測定部位を示す，測定部位は， 横方向として咬合面部の外側幅径 $\mathrm{Oo}-\mathrm{Oo}^{\prime}$ ，歯頸部の外 側愊径 $\mathrm{Co}_{0}-\mathrm{Co}^{\prime}$ と, 咬合面部内側幅径 $\mathrm{Oi}-\mathrm{Oi}$, 歯頸部内 側幅径 $\mathrm{Ci}-\mathrm{Ci}^{\prime}$ の 4 カ所について, 䅠方向として外側高 径 $\mathrm{Oo}-\mathrm{Co}$ と, 内側高径 $\mathrm{Oi}-\mathrm{Ci}$ ” の 2 力所についてそれ ぞれ測定した．また，測定点は蠟型上に印記した基準線 に沿って，横方向では $\mathrm{X}$ 軸とそれに直交するY 軸の 2 カ 所について, 縋方向ではそれぞれ 4 カ所について実測 し，その平均値を測定値とした．なお，実験成績は，ま ず蠟型を鋳造冠の測定部位に準じて実測し，その平均值 を原寸とし，鋳造冠との寸法変化率として求めた.

\section{2. 実験結果}

1）熱澎張抑制埋没材を用いて作製した鋳造冠の横方 向の寸法変化について

（1）咬合面部外側幅径（図 11）

図の縦軸は寸法変化率で，十は原寸に対する鋳造冠の 膨張，一は収縮を表している．横軸は各シリカ濃度で作

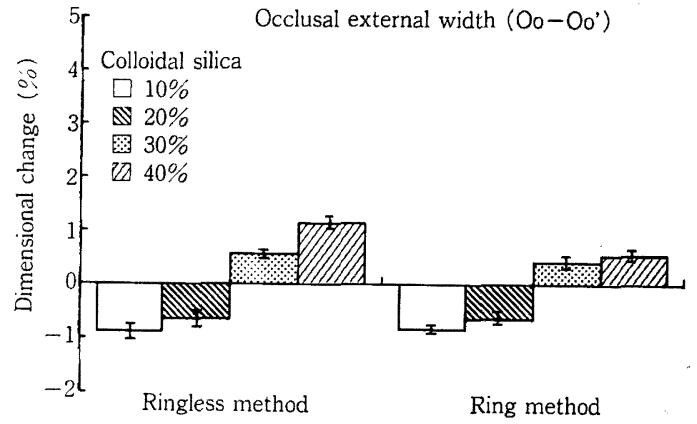

図 11 熱膨張抑制埋没材を用いたときの咬合面部外側 幅径での寸法変化率

製した鋳造冠外側幅径の，図の左側はリングレス法，右 側はリング法の実験結果である.

リングレス法での咬合面部外側幅径の寸法変化率は, シリカ濃度 $10 \%$ では $-0.89 \%, 20 \%$ では $-0.68 \%$ と いずれも収縮を，シリカ濃度 $30 \%$ では $0.55 \%$ の， $40 \%$ では $1.22 \%$ の膨張を示し, シリカ箼度が増すに従って 咬合面部外側幅径は大きくなった.

一方, リング法での咬合面部外側幅径の寸法変化率 は，シリカ濃度 $10 \%$ では $-0.86 \%, 20 \%$ では $-0.67 \%$ と収縮を示し, $30 \%$ と $40 \%$ では, いずれも膨張を示し たが，その差は小さく, $30 \%$ で $0.41 \%, 40 \%$ では 0.55 \%であった.

埋没方法による寸法変化率の差は，シリカ 濃 度 10 , 20，30\% ではそれほどみられないが，シリカ濃度 $40 \%$ ではリング法がリングレス法の約半分の值であった。 こ れはリング壁によって埋没材の膨張が抑制されたためと 考えられる。

(2) 歯頸部外側幅径 (図 12)

リングレス法での歯頸部外側幅径の寸法変化率は, 練 和液のシリカ濃度 $10 \%$ では $-0.79 \%, 20 \%$ では -0.29 \%の収縮を，また，シリカ洤度 $30 \%$ では $1.18 \%, 40 \%$ では $1.53 \%$ の膨張を示し，咬合面部と同様にシリカ 濃 


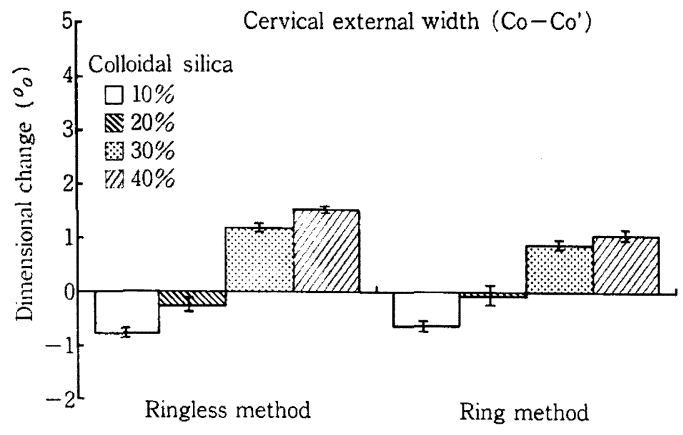

図 12 熱膨張抑制埋没材を用いたときの歯頸部外側幅 径での寸法変化率

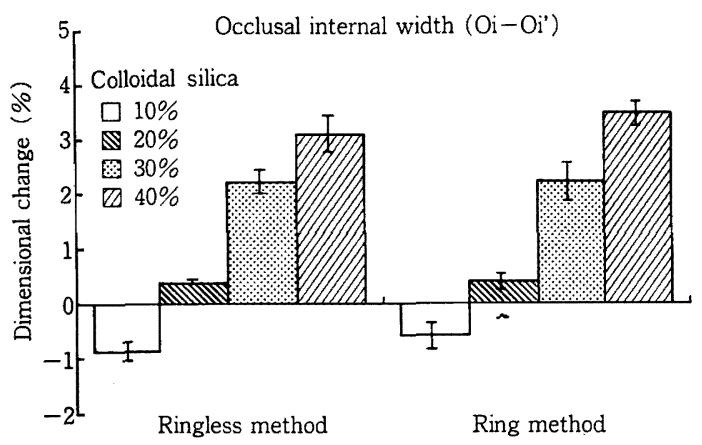

図13 熱膨張抑制埋没材を用いたときの咬合面部内側幅 径での寸法変化率

度が増すほど膨張が大きくなる傾向がみられた。

リング法での歯頸部外側幅径の寸法変化率は，シリカ 濃度 $10 \%$ では $-0.65 \%$ の収縮を示したが, $20 \%$ ではほ ぼ原寸に近いー0.09\%の值であった. また，シリカ䟴 度 30\%と $40 \%$ ではいずれも膨張を示したが，咬合面部 の結果と同様にその差は小さかった.

埋没方法による差は，咬合面部外側幅径と同様に，リ ング法のシリカ濃度 $40 \%$ において膨張の抑制が認めら れ，リングレス法よりも膨張が小さかった。

一方, 外側部の咬合面部と歯頸部の寸法変化率を比較 した場合，いずれの埋没方法でもシリカ濃度に関係なく 䤻造冠の軸面部外側は, 咬合面部よりも歯頸部での膨張 が大きく現れる結果となった。

(3) 咬合面部内側幅径（図 13）

リングレス法での咬合面部内側幅径の寸法変化率は, 練和液のシリカ濃度 $10 \%$ では $-0.89 \%$ の収縮を示し， 咬合面部外側幅径と同じ值となった. しかし，シリカ濃 度 $20 \%$ では $0.37 \%$ の膨張を示し，咬合面部外側幅径が 収縮を示したのと異なった結果となった。 さらに，シリ

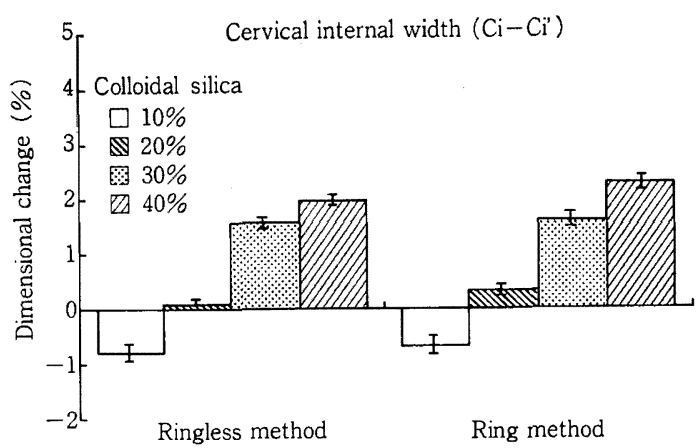

図 14 熱膨張抑制埋没材を用いたときの歯頸部内側幅径 での寸法変化率

カ濃度が $30,40 \%$ と増すに従って $2.20,3.08 \%$ と非常 に大きく膨張した.

リング法での咬合面部内側幅径も, リングレス法と同 様の傾向を示し，シリカ濃度 $10 \%$ では収縮しているも のの, $20 \%$ で膨張を示し, シリカ濃度の増加に従って膨 張の程度は大きくなった. これらの値はリングレス法と 同様に咬合面部外側幅径よりむ大きかった. また，シリ カ濃度 $40 \%$ での外側幅径にみられた膨張の抑制は内 側 部では生じていなかった.

一方, 埋没方法による差はシリカ䟴度 $10 \%$ でわずか に認められたものの, その他のシリカ濃度ではほとんど 認められず, ほぼ均等な膨張の傾向を示していた。

(4) 歯頸部内側幅径（図 14）

リングレス法での歯頸部内側幅径の寸法変化率は, 練 和液のシリカ濃度 $10 \%$ では歯頸部外側幅径とほぼ 同 様 の - $0.81 \%$ の值を示した. $20 \%$ では歯頸部外側幅径が 収縮を示したのに対し，原寸に近い $0.08 \%$ の值を示し， 咬合面部内側幅径と同様の傾向であった. さらに，30, 40\% での膨張は, 歯頸部外側幅径よりも大きかったが, 咬合面部内側幅径よりは少なく, その差も小さかった.

リング法でも，いずれのシリカ濃度においてもリング レス法とほぼ同様の傾向を示した.

また, 埋没方法による差は咬合面部内側幅 径と同様 に，、ずれのシリカ濃度においてもほぼ均等な膨縮を示 した.

一方, 内側部の咬合面部と歯頸部の寸法変化率を比較 すると，シリカ濃度 $10 ， 20 \%$ ではほとんどその差はみ られないが，シリカ濃度 30, 40\% では咬合面部が歯 頸 部より大きく膨張し, 外側部とは逆の結果を示した.

2）熱膨張抑制埋没材を用いて作製した鋳造冠の縦方 向の寸法変化について 




図 15 熱膨張抑制埋没材を用いたときの外側高径での寸 法変化率

a) 外側高径 (図 15)

リングレス法での外側高径の寸法変化率は, 練和液の シリカ濃度 $10 \%$ では $-0.75 \%, 20 \%$ ではほぼ原寸を示 し，30\% 以上では膨張が大きく現れ，40\% では $2.05 \%$ の膨張を示した.

リング法の場合には，シリカ濃度 $10 \%$ では $-0.62 \%$, $20 \%$ では $0.20 \%$ であったが，シリカ濃度が $30 \%$ と 40 \%ではリングレス法と同様に膨張が大きくなった.

埋没方法による差は, 横方向の外側部とは異なり, リ ング法がリングレス法よりもわずかに膨張が大きくなる 傾向を示した.

b) 内側高径 (図 16)

リングレス法での内側高径の寸法変化率は, 練和液の シリカ濃度 $10 \%$ では $-0.84 \%, 20 \%$ では $0.71 \%$ であ ったが，シリカ濃度が $30 ４ 40 \%$ と増すと膨張は大きく 現れ，40\%では $4 \%$ もの值を示した。

リング法での内側高径の寸法変化率は, シリカ濃度 10,20\% ではリングレス法と同様の傾向を示したが, 30, 40\%とシリカ濃度が増すに従って大きく膨張し, その值 はリングレス法よりも大きかった.

埋没方法による差は, 外側高径と同様にリング法がリ ングレス法よりむわずかに大きな膨張を示したが，リン グ・リングレス法ともにシリカ濃度に関係なく，横方向 の内側部之同様に，ほほ等しい膨縮変化を示した.

また, 内・外側部の寸法変化を比較すると，シリカ濃 度 $10 \%$ 以外は外側部に比べ内側部が埋没方法に関 倸な く大きな膨張を示した.

3）無膨張埋没材を用いて作製した鋳造冠の縦・横方 向の寸法変化について

対照として用いた無膨張埋没材の実験結果を図 17 に 示す. 横方向の内 - 外側幅径および縦方向の内 - 外側高 径のいずれも，埋没材が膨張しないため $1.08 〜 1.30 \%$



図 16 熱膨張抑制埋没材を用いたときの内側高径での寸 法変化率

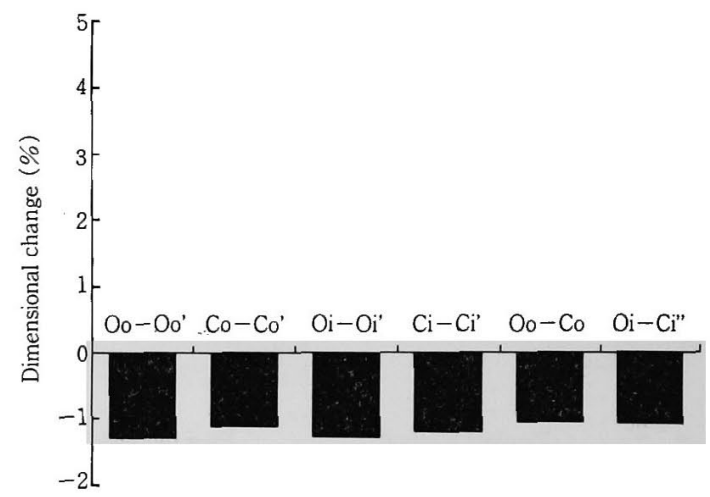

図 17 無膨張埋没材を用いたときの各測定部位での 寸法変化率

の収縮を示した、しかし，各測定部位間での寸法変化率 の差は小さく, ほぼ均等な寸法変化を示し, 蠟型に対し 相似形的に寸法変化をしていることが明らかである.

\section{3. 考 察}

本来, 変形のない鋳造冠とは蠟型と同形・同大でなけ ればならない，ところが，多くの先人によるこれまでの 研究結果は，作製された鋳造冠はすべて変形を伴ってお り，その変形の原因は吸水膨張を含む硬化時膨張である とされている10,13,15,24,26 28). しかし，これらの研究に用 いられた埋没材はすべて硬化時膨張と熱膨張の両者を利 用したものであり，硬化時膨張のみを用いて鋳造冠の寸 法変化を観察した報告はみあたらない.

そこで，著者は実験 1 で試作した熱膨張抑制埋没材を 用い，硬化時膨張のみで金属の鋳造収縮を補鰂すると， 鋳造冠各部の寸法にどのような影響を与えるかを検討し た.この埋没材は練和液のコロイダルシリカ溶液の箼度 を変化させると任意の硬化膨張量が得られるので，本実 




図 18 熱膨張抑制埋没材を用いたときの軸面部外側 の変形表示図

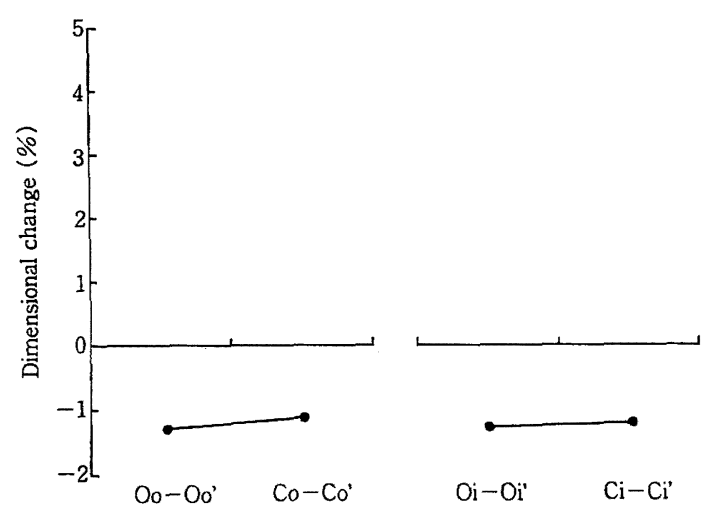

図 19 無膨張埋没材を用いたときの軸面部内・外側 の変形表示図

験ではコロイダルシリカ溶液の濃度を硬化時膨張の小さ いものから大きいものまで 4 種類に変化させて実験を行 った. さらに，埋没条件は臨床的に高い精度が得られる といわれているシリコーンラバーリングを用いたリング レス法5,24,34) と，カオウールを 1 枚ライニングしたリン グ法の 2 種類について行った. それらの結果を横方向と 縦方向の変形に総括し, 考察を加える.

1) 横方向

熱膨張抑制埋没材を用いて作製した鋳造冠軸面部外側 の咬合面部（図 11）と歯頚部（図 12）では，シリカ濃度 $10,20 \%$ でともに収縮を示したが，シリカ濃度 $30,40 \%$ ではいずれも膨張し, 濃度の増加に従って大きくなる傾 向がみられた. そして，これらの值はリングレス法がリ ング法よりわずかに大きく現れた. これは使用した緩衝 材の緩衝効果の差と考えられ，カオウール1枚ライニン グのリング法ではリング壁による埋没材の膨張の抑制が 生じたためと考えられる.

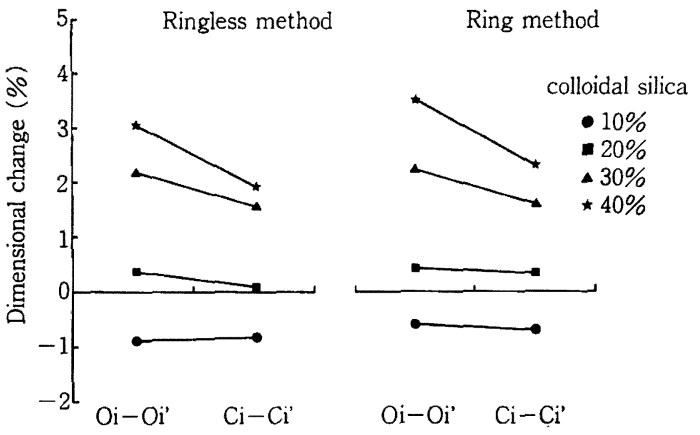

图 20 熱膨張抑制埋没材を用いたときの軸面部内側 の変形表示図

注目すべきことは，歯頸部外側幅径の膨張がシリカ濃 度に関係なく, すべて咬合面部外側幅径よりも大きな值 を示したことである，この関係を表したのが図 18 の軸 面部外側の変形表示図で, 縦軸は寸法変化率を, 横軸は 各測定部位を表している.この変形表示図では, 咬合面 部と歯頸部の 2 力所の測定部位を結んだ直線が水平でし かも0に近いほど鋳造冠軸面部外側の変形が小さいとい える. 変形表示図からも明らかなように, 本実験での鋳 造冠軸面部外側は, 練和液のシリカ濃度, リング・リン グレス法の埋没条件に関係なく咬合面部から歯頸部に向 かって膨張が大きくなる傾向, いわゆる「すそ開き」の 変形が生じていることが認められ, 吉田 ${ }^{2)}$ や小正 ${ }^{15)}$ の結 果と一致していた. 一方, 図 19 は無膨張埋没材を用い た場合の軸面部の変形表示図で, 図の左側は軸面部外側 を，右側は軸面部内側を示している．外側ではわずかに 「すそ開き」が認められるものの, 本実験で最も変形が 少なかったシリカ濃度 10\% の結果より少ないことがう かがえる.これらの結果から勘案すると軸面 部外側の 「すそ開き」の変形は, 硬化時膨張が関与していること が考えられる.

横方向軸面部内側の咬合面部 (図 13), 歯頸部 (図 14) はともに，いずれの埋没条件でもシリカ浱度 $10 \%$ では 収縮を示しているが, $20 \%$ ではほぼ原寸に近い值を示し た. $30,40 \%$ のシリカ濃度では膨張が著しく大きくなる 傾向がみられ，その膨張量はリング・リングレス法とも ほぼ同程度であった。これは鋳型空間に囲まれた中子部 が，硬化時にリング壁やシリコンラバーの影響をほとん ど受けることなく，独立した自由な膨張を示し，しかも， 鋳型の強度が大きく，泠却後の収縮も小さいため，金属 の鋳造収縮を抑制した結果であると考えられる．これに 対して, シリカ濃度 $10,20 \%$ で収縮，あるいは膨張が 小さく現れたのは $30,40 \%$ に比べて鋳型の強度が弱く， 
表 4 使用埋没材の硬化時の温度 (最高温度)

\begin{tabular}{c|cc|c|c|c}
\hline \hline \multicolumn{2}{c|}{ Material } & \multirow{2}{L}{$\begin{array}{c}\text { L/P } \\
\text { Powder }\end{array}$} & Liquid & $\begin{array}{c}\text { Ringless } \\
\text { (Silicone rubber) }\left({ }^{\circ} \mathrm{C}\right)\end{array}$ & $\begin{array}{c}\text { Ring } \\
\text { (Kaowool liner) }\left({ }^{\circ} \mathrm{C}\right)\end{array}$ \\
\hline \multirow{3}{*}{ T.E. } & Colloidal & 10 & & 85 & 85 \\
& silica & 20 & \multirow{2}{*}{0.16} & 83 & 84 \\
& $(\%)$ & 30 & & 83 & 85 \\
& & 40 & & 83 & 85 \\
\hline N.E. & Water & 0.16 & 82 & - \\
\hline
\end{tabular}

冷却後の残留膨張も非常に小さいために金属の鋳造収縮 の影響を大きく受けた結果と思われる.

次に, 軸面部内側の咬合面部と歯頸部の関係を知るた めに図 20 に変形表示図を示した. 硬化時膨張の小さい シリカ濃度 $10,20 \%$ では, 両者の関係は, リングの有 無にかかわらずその直線はほぼ水平で変形が少ないこと を示している，ところが膨張が大きく現れるシリカ濃度 $30 \%$ では, 両者の関係を示す直線は明瞭に右さがりとな った.このことは, 軸面部内側では咬合面部から歯頸部 に向かって膨張が小さくなる「先細り」の変形が生じて いることを示している．さらに，シリカ檂度 $40 \%$ では その傾向がいっそう著明に現れていることから，硬化時 膨張が増大寸るに従って変形も大きくなることが明らか である.この「先細り」の変形の原因について小西ら ${ }^{14)}$ は, クリストバライト埋没材を使用したときの中子部の 膨張は, 硬化時の䁶型の制約とともに, 熱膨張時の変形 膨張が影響していると考察している．しかし，本実験の 埋没材は熱膨張を起こさないことから考えると，この考 察とは矛盾する.

ところで本実験に使用した埋没材はリン酸塩系埋没材 であり，その硬化時膨張は発熱を伴った硬化機序である ことは知られている. そこで, 本実験に用いた 2 種類の 埋没材の硬化熱を測定することにした. 測定は円錐台に 植立した冠形態の蠟型の咬合面部に, 直径 $0.2 \mathrm{~mm}$ の熱 電対を付着させ, 埋没材のリングへの注入直後から 2 時 間経過後までの硬化熱を計測した. その最高温度を表 4 に示す，硬化熱は，熱膨張抑制埋没材ではいずれの埋没 条件でも, 練和開始 8 分ごろに約 $85^{\circ} \mathrm{C}$ 前後の最高温度 となった. 一方, 使用したグリーンインレーワックスの 軟化温度はメーカー表示で $52^{\circ} \mathrm{C}$ であり, 埋没材の硬化 熱と考え合せると，蟀型は埋没材の硬化過程において軟 化, 一部溶融しているものと思われる．したがって，軟 化した蠟型に取り囲まれた中子部の埋没材は，比較的制 約を受けることなく自由に膨張することができる．しか しながら, 外側部の埋没材と連なる歯頸部側の中子部の
膨張は外側部の埋没材の影響を受けると考えられ，咬合 面部に近くなるほど中子部の埋没材は自由な膨張ができ ると考えれば，咬合面部が歯頸部より大きくなったこと についても理解できる. 一方, 無膨張埋没材で作製した 鋳造冠軸面部内側の変形表示図 (図 9 の右図) はほぼ水 平で変形のない様相を呈しているが，これは埋没材自体 が膨張しないためと考えられる.これらの結果から考察 すれば，硬化時膨張が鋳造冠内側部の変形にも関与して いることは明らかである.

さらに, 横方向の内・外側部を比較すると, シリカ濃 度, 埋没条件に関倸なく軸面部外側の膨張は軸面部内側 より小さく,この差は, 特にリング法で作製したシリカ 濃度 $40 \%$ の場合に著明であった. これは，軸面部内側 では冷却収縮が小さく, しかも強度も大きな中子の存在 が金属の鋳造収縮を抑制するのに対し，軸面部外側では 金属の鋳造収縮量分だけ収縮するために内側部の膨張が 大きく現れたと考えられる．したがって，肉の厚、咬合 面部で内側部と外側部の差が大きく現れたのであろら. また, 埋没材の膨張が大きすぎると, リング内の緩衝材 の緩衝効果が発揮されず, 横方向への膨張がリング壁で 抑制されて逆に鋳型空間方向へ向からため, 外側部の膨 張が抑制されたとも考えられる. その結果, 鋳造冠軸面 部の厚さの減少がうかがえる. しかも, シリカ浱度が増 加するに従ってその差が大きくなり，咬合面部に近いコ ンタクトポイント付近で特に厚さの大幅な減少が生じて いると考えられる.

2) 縦方向

縦方向の外側高径にみられる変形（図 15）は，いずれ の埋没条件でもシリカ濃度 10\% では収縮を示したが, シリカ濃度 $20 \%$ でほぼ原寸に近くなっていた. また, $30,40 \%$ とシリカ濃度が増すに従って膨張は大きくな り，しかも，その值はリング法がリングレス法よりも大 きく現れた. これは, 前述したように横方向への膨張が シリコーンラバーやリング壁の存在によって抑制され, その一部が変形膨張となって緃方向に現れたためと考え 


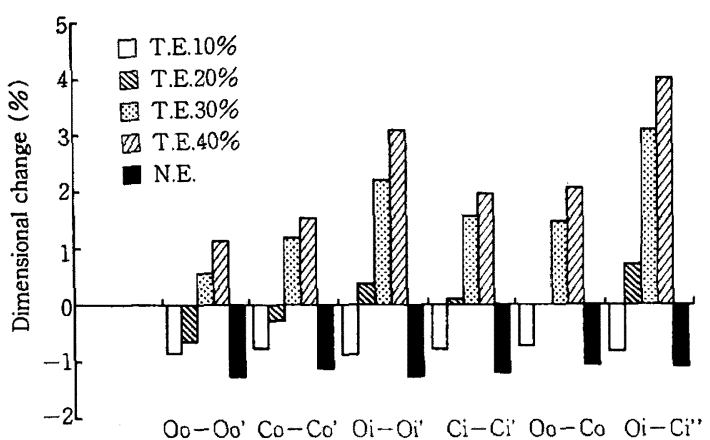

図 21 各測定部位からみた鋳造冠の変形 (リングレス法)

られる.そして，リング壁による抑制がシリコーンラバ ーより大きいのであろう.

縦方向の内側高径にみられる変形 (図 16) はシリカ濃 度 $10 \%$ で収縮を示しているものの, シリカ濃度が増す ほど非常に大きな膨張が観察され，シリカ濃度 $40 \%$ では 実験 1 で測定した埋没材自身の膨張量 $3.11 \%$ を超える $4 \%$ もの大きな膨張を示した. これは，いかに中子部が 自由に膨張し，冷却収縮も小さく，また，強度が大きい としても内側高径が $4 \%$ も膨張するとは考えられない. 何か鋳型に異常な膨張を生じさせる原因があるのではな いだろらか. あえて考えるならば，内側部は鋳型空間に 取り囲まれている上に，歯頸部側は開放側と連なってい るため,一部横方向の変形膨張の影響を受けたとしか考 えられない.

一方, 内・外側高径を比較してみると，いずれのシリ カ裖度でも内側部の膨張が外側部よりも大きく, 鋳造冠 軸面部と同様に咬合面部でも厚さの減少が考えられ，し かも，硬化膨張量が增すほど大幅な厚さの減少が生じて いることがうかがえる.

最後に, 鋳造冠全体の変形を知る目的で, 各測定部位 での変化率を練和溶液のシリカ濃度別に棒グラフに表し た. 図 21 はリングレス法, 図 22 はリング法である.こ のグラフを先に述べた変形表示図と同様に，おのおのの 濃度の棒グラフの頂点を仮想線で結んだとすると，その 仮想線が水平でしかも0に近いほど鋳造冠の変形は小さ いといえる.グラフから明らかなように, 硬化時膨張の 小さい $10 \%$ シリカ箼度ではすべて収縮しているものの ほぼ直線状を示し，変形が小さいといえる．また対照と して用いた無膨張埋没材ではさらに変形は小さい.シリ カ濃度が $20,30,40 \%$ と增加するに従って膨張も大きく なり，埋没方法に関係なく仮想線は内側部の測定部位で の変化率が突出する曲線形態を示している. しかも, シ

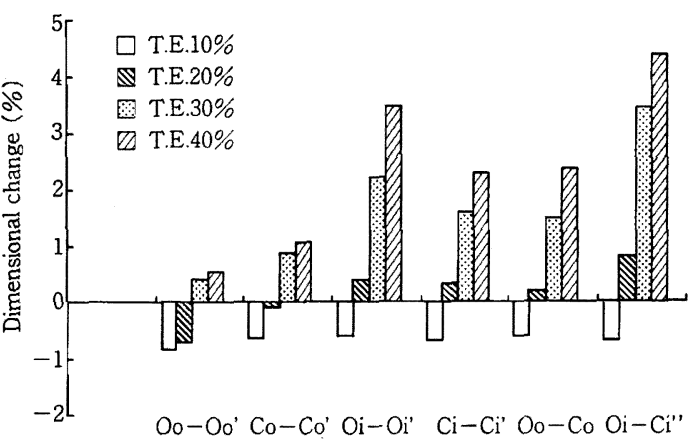

図 22 各測定部位からみた鉱造冠の変形 (リング法)

リカ濃度の増加とともに，いいかえると膨張が大きくな るに従って, 変形も大きくなる. すなわち, 硬化時膨張 が小さければ測定部位間の変化率の差も小さく, 比較的 変形の少ない鋳造冠が得られるが，硬化時膨張を大きく 寸ればそれに伴う変形も大きくなることが明白となっ た.

\section{IV. 総 括}

金属の鋳造収縮の補償を硬化時膨張のみに依拠して良 いかどうかを検討する目的で，まず，硬化時膨張のみで 熱膨張がないリン酸塩系埋没材を試作した，次に，この 試作埋没材を 4 種類のコロイダルシリカ溶液で練和して 鋳造冠を作製し，鋳造冠各部の寸法がどのような影響を 受けるかを比較検討した.

試作した熱膨張抑制埋没材について

1.コロイダルシリカ溶液の濃度を $10,20,30,40 \%$ とした場合, シリカ濃度が増すに従って, 硬化時間は短 くなり，圧縮強さは大きくなる傾向を示した.

2. 熱膨張抑制埋没材の硬化時膨張量は, 練和液のシ リカ濃度が増すに従って大きく現れた. 泠却収縮量は, 市販埋没材と比較して非常に小さかった。

3. 緩衝材による硬化時膨張量への影響は, シリコー ンラバーを用いたものが，いずれのシリカ濃度でも，力 オウールよりも膨張が大きかった.

鋳造冠の変形について

1. 咬合面部ならびに歯頸部の外側幅径は, シリカ莀 度 $10 \%$ と $20 \%$ ではリング ・ リングレスの埋没法ともに 収縮がみられたが，濃度が増加するに従って膨張する傾 向を示した. しかし, リング法でのシリカ濃度 $40 \%$ で は, 膨張の抑制が認められた。 また, 歯頸部外側幅径の 膨張は, シリカ濃度に関係なくすべて咬合面部よりも大 きな値を示した。 
$34-444$

2. 咬合面部ならびに歯頸部の内側幅径は, シリカ濃 度 $10 \%$ ではリング・リングレスの埋没法ともに収縮を 示したが, シリカ濃度が増加するに従って外側幅径と同 様に膨張が大きく現れた．しかし外側幅径とは逆に，咬 合面部の值が歯頸部よりも大きくなる傾向を示した. ま た, 内側幅径の膨張はいずれも外側幅径より大きな值を 示した.

3. 外側高径と内側高径は，埋没法に関係なくシリカ 濃度 $10 \%$ でともに収縮を示したが，濃度が増すに従っ て膨張が大きくなった。 また，内側高径はシリカ濃度 $10 \%$ 以外ですべて外側高径より大きな膨張を示した.

\section{V. 結 論}

硬化時膨張のみに依拠して鋳造冠を作製すると様々な 変形が生じることが明らかとなった. したがって, 現在, 歯科界で使用されている硬化時膨張と熱膨張の両者を利 用した鋳造法では，熱膨張が関与する以前の硬化時膨張 の段階で，すでに変形が起きていると考えられ，硬化時 膨張が鋳造冠の変形の主要因をなしているといえる.

稿を終えるにあたり，終始ご想篤なるご指導とご校閲を賜った 故西浦 恂教授, 権田悦通教授に哚甚の感謝を捧げます. また, 貴重なご助言を賜りました神奈川歯科大学歯科理工学教室上新和 彦教授に深謝いたします. 本研究に対し直接ご指導とご校閲を賜 った小正 裕講師ならびに筆本秀和非常勤講師に心からの謝意を 表しますとともに，ご援助いただいた各位に感謝いたします. 最 後に, 試料の提供にご協力くださいました大成歯科工業 (株) 研 究室の皆様に厚くお礼申し上げます。

本論文の要旨は, 第 80 回日本補緅歯科学会学術大会（1988 年 10 月 23 日, 岐阜) ならびに第 379 回大阪歯科学会例会 (1989年 3 月 18 日, 大阪) において発表した.

\section{文献}

1) Coleman, R.L. : Physical properties of dental materials (II) progress report of research on the dental casting process, Dent Cosmos, $68: 743 \sim 764,1926$.

2）吉田恵夫 : 歯科鋳造法の実用的精度について, 補緅誌, 2 : 159 186, 1958.

3）総山孝雄：精密鋳造に関する研究，歯材器誌， $7: 36 \sim 55$, 1962.

4）上新和彦, 蕈 淳三：りん酸塩を結合材とした埋没材の諸 性質とその適合性について, 歯理工誌, $11: 124 \sim 133$, 1970.

5）真坂信夫：ワンピースキャストプリッジの鋳造精度に関す
35 巻 3 号 (1991)

る研究, 歯科学報, $70: 725 \sim 758,1970$.

6）上条智生：鋳造体の変形に関する研究，歯理工誌， $13: 56$ $\sim 88,1972$.

7) 大村国明, 片桐保昭, 松野 滉ほか: 各種技法による全部 鋳造冠の適合度の比較, 歯材器誌, $26: 30 \sim 36,1972$.

8）西岡二二夫：鋳造時収縮変化の異方性に関する 基礎的研 究, 九州歯会誌, $28: 355 \sim 378,1974$.

9）上新和彦：より良い鋳造体をつくるために，鹿歯紀， 9： $21 \sim 29,1989$.

10）J $\phi$ rgensen, K.D. : 和久本貞雄, 久光 久訳 : インレーと クラウン 歯科精密鍀造の理論と実際, 154 167, 昰林, 東京, 1989.

11）上新和彦, 黒田拓治 : 鋳造体の厚さに関する研究, 歯理工 誌, $12: 72 \sim 78,1971$.

12）中西哲生 : 鋳造冠における再現性とセメント合着後の適合 性に関する研究，歯科学報, $75 ： 1797 \sim 1817 ， 1975$.

13）筆本秀和：試作無膨張埋没材を用いての鋳造体の変形につ いて, 補緅誌, $24: 301 \sim 321,1980$.

14）小西正裕, 渡辺嘉一, 横塚繁雄：せっこう系埋没材を用い た鋳造冠内面の形状変化, 補緅誌, $29: 102 \sim 120,1985$.

15）小正 裕：鋳造冠の変形に関する研究一とくに厚さを中心 とした育形についてー，歯材器, $5: 529 \sim 554,1986$.

16）羽田晧而, 新谷明喜, 横塚繁雄ほか : 高温埋没材を用いた 鋳造冠内面の形状変化, 補緅誌, $32: 358 \sim 373,1988$.

17) Mahler, D.B. and Bruce, A.A. : The influence of various factors on the effective setting expansion of casting investments, J Prosthet Dent, $13: 365 \sim 373,1963$.

18）東口茂治：歯科精密鋳造法に関する研究一とくに埋没材の 凝固膨張を抑制した鋳造法について一, 歯科医学, $31: 1$ 16, 1968.

19）永沢 栄, 伊藤充雄, 高橋重雄ほか：鋳造精度に関する研 究その 3 埋没材の硬化時における膨張圧, 膨張量およ び発熱温度に対する緩衝材の影響について, 歯科学報, 75 : $286 \sim 292,1975$.

20）永沢 栄, 伊藤充雄, 中西哲生ほか: 精密鋳造に関する研 究 (その9) ワックスパターンに対する埋没材の硬化膨張 の影響について, 松本歯学, $5: 27 \sim 34,1979$.

21）上新和彦, 藤井孝一, 有川裕之ほか：埋没材の膨張と鋳造 体の寸法との関連性 第 1 報 埋没材の膨張の測定方法, 歯材器, $4: 334 \sim 338,1985$.

22）上新和彦, 藤井孝一, 有川裕之ほか：埋没材の膨張と鋳造 体の寸法との関連性 第 2 報 石こう系埋没材を用いた場 合, 歯材器, $4: 339 \sim 343,1985$.

23) Meiser, E.T., Rijk, W.G. Tesk, J.A. et al : Internal setting expansion of a dental casting investment measured with strain gauges, J Prosthet Dent, $53: 870 \sim 873$, 1985.

24) Junner, R.E. and Stevens, L. : Anisotropic setting ex- 
pansion of phosphate bonded investment, Aust Dent J, $31: 434 \sim 439,1986$.

25）上新和彦, 藤井孝一, 有川裕之ほか：荷重下における埋没 材の硬化時膨張, 歯材器, $7: 366 \sim 370,1988$.

26) Skinner, E.W. : The role of investment setting expansion in gold compensation casting techniques, Dent Cosmos, $75:$ 1009 1019, 1933.

27) Steven, L., Okamoto, A. and J $\phi$ rgensen, K.D. : Dimensional change in mold space on setting of phosphate bonded investment, Aust Dent J, $30: 281 \sim 284,1985$.

28) Watanabe, A. and J $\phi r g e n s e n, K . D .:$ Thermal expansion of dental casting alloys and phosphate bonded investment, Dent Mater J, $5: 21 \sim 25,1986$.

29）澤田武仁：コロイダルシリカ溶液で練和したリン酸塩系埋 没材の硬化機序ならびに水和膨張について, 歯材器誌, 32 :
6〜16, 1975.

30）金竹哲也：歯科理工学通論, 永末書店, 京都：191 195, 1980.

31）浦部素直, 岩本 修, 内山照夫ほか：リン酸塩系鋳型材の 硬化膨張機椿, 日本歯科理工学会北海道・東北, 関東, 中 部 3 支部共催学術講演会講演集 : 31 32, 1982.

32）高橋純造, 岡崎正之,木村 博ほか：リン酸塩系埋没材の 硬化膨張 第 1 報 コロイダルシリカ液の影響, 歯材器, $4: 496 \sim 503,1985$.

33）高橋純造, 岡崎正之, 木村 博ほか：リン酸塩系埋没材の 硬化膨張 第 2 報 結合材量および基材粒度の影響, 歯材 器, $4: 666 \sim 671,1985$.

34）吉成正雄，鈴木義博，住井俊夫：リングレス鋳造法による 鋳造精度, 歯科学報, $75: 986 \sim 993,1975$. 